\title{
The Northern Shrike
}

\author{
By R. D. Symons
}

A winter bird of great interest to me is the Northern Shrike, whose song, heard on a sunny March morning is music indeed.

They are great mousers, and habitually hang about hay-stacks and corrals, where the meadow voles live in hundreds. These voles are very destructive, burrowing their runways through and

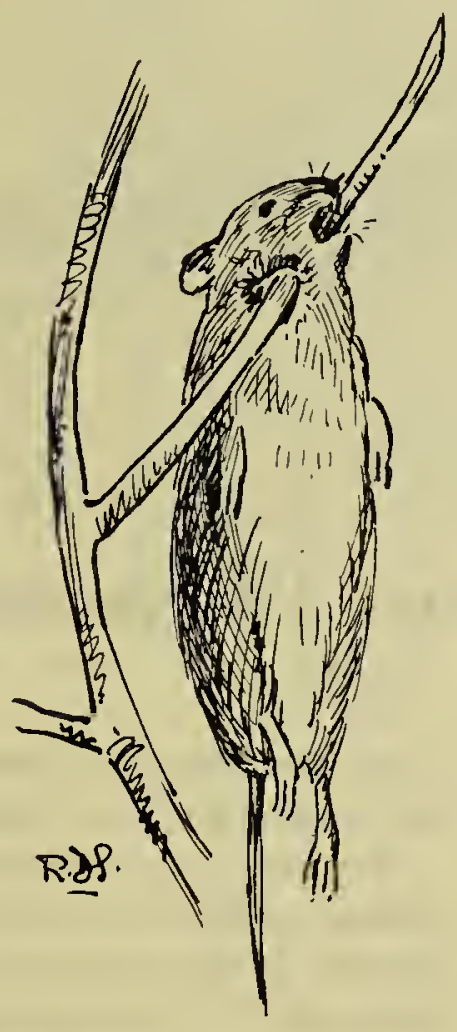
through the stacks, sometimes to the point of making them as full of holes and runways as a sponge, and leaving bushels of short chaff where they have been feeding.

One year I had a heavy crop of frozen oats which I mowed for green feed and put into large bunches, since the weather and the imminence of winter prohibited stacking. After the snow came I began to haul this feed to the cattle, taking a load a day with team and sleigh. On opening up the first bunch, I disclosed several vole nests from which the little animals crawled and immediately hid themselves under the forage, until such time as the removal of another fork-full aga in exposed them when they scampered in different directions and began to burrow into the surrounding snow. Presently a shadow on the snow caused me to look up and there was a Northern Shrike hovering exactly like a falcon, within a few feet of my head.

Regardless of my energetic forking the little bird suddenly swooped, struck a vole a violent bl ow on the head which caused it to roll over as if paralysed, and then again darted in, seized the vole by the scuff of the neck with its hook-like bill and flew off to a willowbluff some 200 yards distant. The typical bee-like flight of the shrike was greatly slowed down by the weight in its bill. Several times the bird was so dragged down as to appear to touch the snow but with great effort and with difficulty keeping its head up and tail down, the bird reached the willows. I could not see what it did but by the time I moved on to another bunch of hay the bird was back and repeated the performance.

Sometimes a vole will show fight, standing on its hind end; small front paws placed either side of its head, teeth showing, eyes snapping, and uttering a shrill provocative chatter. At such times the shrike was very wary and hovered sometimes for several minutes around its prey before closing in. Not once did I see a shrike put its feet to the snow when mousing.

A few days later a second shrike entered the lists and from then on the two birds played shuttle back and forth between my sleigh and the willows.

Promptly every morning at eight as I pulled out of the yard the two birds met me at the edge of the field and as I finished loading they disappeared. This went on from about Dec. 2nd until February 5th, by which time all of the field had been cleared.

Later I went to the willow bluff and found literally hundrens of voles skewered on the moose-browsed willow branches in the manner illustrated -never any other way. The sharp point on the branch is inserted at the side of the throat at base of jaws. A sharp tug by the bird causes it to pierce the skin. The head is then drawn down by the bird's foot until the twig projects through the vole's mouth -- in the manner of stringing up fish. 